\title{
HERBICIDE SELECTIVITY BY DIFFERENTIAL METABOLISM: CONSIDERATIONS FOR REDUCING CROP DAMAGES
}

\author{
Saul Jorge Pinto de Carvalho ${ }^{1}$; Marcelo Nicolai ${ }^{1}$; Renato Rodrigues Ferreira ${ }^{2}$; Antonio Vargas \\ de Oliveira Figueira ${ }^{2}$; Pedro Jacob Christoffoleti ${ }^{3 *}$ \\ ${ }_{2}^{1}$ USP/ESALQ - Programa de Pós-Graduação em Fitotecnia. \\ ${ }_{2}^{2}$ CENA/USP - Lab. de Melhoramento de Plantas, C.P. 96 - 13400-970 - Piracicaba, SP - Brasil. \\ ${ }^{3}$ USP/ESALQ - Depto. de Produção Vegetal, C.P. 9 - 13418-900 - Piracicaba, SP - Brasil. \\ *Corresponding author < pjchrist@esalq.usp.br>
}

\begin{abstract}
Herbicide selectivity is an agricultural technology largely exploited in chemical strategies of weed control. The joint action of several protection mechanisms avoids phytotoxicity from herbicide treatment, maintaining the level of agronomically accepted damage to a minimum, or even totally avoiding them. The major mechanism of herbicide selectivity derives from the differential metabolism between weed and crop plant species, with weeds presenting a limited ability to perform it under agronomically recommended conditions. In this case, phytotoxicity can be interpreted as an overcoming of the maximum protection capacity offered by the mechanisms of selectivity, or when considering metabolism as the main factor, the overcoming of the inherent plant ability to detoxify a particular molecule. Considering that herbicide metabolism requires energy disposal, symptoms of phytotoxicity characterize an additional waste of energy that should not be accepted as a natural physiologic response; therefore it might result in yield losses. To avoid or minimize crop losses or damages, it is required that herbicide application recommendations are based on results from rigorously conducted selectivity experiments, as well as that there is an increase in the awareness of growers about the best use of each product.

Key words: phytotoxicity, injuries, yield, experimental design, crop management
\end{abstract}

\section{SELETIVIDADE DE HERBICIDAS POR METABOLISMO DIFERENCIAL: CONSIDERAÇÕES PARA REDUÇÃO DE DANOS EM CULTURASAGRÍCOLAS}

\begin{abstract}
RESUMO: A seletividade dos herbicidas é uma tecnologia agrícola que tem sido vastamente explorada nas estratégias de controle químico de plantas daninhas. É resultado da ação conjunta de diversos mecanismos que protegem a cultura da fitotoxicidade dos tratamentos herbicidas, mantendo-a com níveis de injúrias aceitáveis agronomicamente, ou mesmo na ausência destas. O principal mecanismo de seletividade dos herbicidas é o metabolismo diferencial desses produtos entre plantas daninhas e cultivadas, em que, nas situações de recomendação agronômica, as plantas daninhas são menos hábeis em realizá-lo. Neste caso, a fitotoxicidade pode ser entendida como a suplantação da capacidade máxima de proteção oferecida pelos mecanismos de seletividade ou, considerando o metabolismo como o principal mecanismo, como a superação da capacidade intrínseca da espécie em detoxificar determinada molécula. Considerando-se que o metabolismo de herbicidas envolve gasto de energia, os sintomas de fitotoxicidade caracterizam um segundo gasto energético que não deve ser aceito como uma resposta físiológica natural, portanto pode resultar em perdas de rendimento das culturas. Para evitar ou minimizar as perdas ou injúrias às culturas, é necessário que as recomendações de herbicidas sejam baseadas em trabalhos de seletividade conduzidos com adequado rigor experimental; bem como é importante a conscientização dos agricultores quanto a melhor forma de utilizar cada produto.

Palavras-chave: fitotoxicidade, injúrias, rendimento, delineamento experimental, manejo
\end{abstract}

\section{INTRODUCTION}

In agriculture, chemical control of weeds is based on herbicide selectivity and it can be defined as the differential response level among species after the application of a particular molecule (Oliveira Júnior, 2001). Selectivity refers to the capacity of a particular herbicide to eliminate weeds in a crop, without af- 
fecting yield or quality of the final product (Negrisoli et al., 2004). Selectivity is intrinsically related with the fact that plant species respond differently to the same herbicide (Devine et al., 1993).

Despite the fact that herbicide selectivity has been long recognized in Weed Science, the concept is incomplete because it commonly excludes the importance of the mechanisms involved. Herbicide selectivity is derived from differences among plants in interception and uptake of herbicides; in Metabolic pathways and rates; in target-enzyme sensitivity (site of action); and in tolerating product phytotoxicity (Devine et al., 1993). Further, herbicide selectivity can be based not only in biotic characters, but also in product characteristics; mode of application (in time and space); use of antidotes or safeners and genetic engineering (Oliveira Júnior, 2001).

Herbicide selectivity should not be evaluated only by the product itself, but considering the interaction between other factors, including environment, rate, and crop aspects (Oliveira Júnior, 2001). Therefore, selectivity must be seen as the joint consequence of several plant protection factors to minimize or exclude injuries. Among selectivity factors associated with plant traits, the differential metabolism of herbicides is one of the most important (Devine et al., 1993; Cole, 1994; Hatton et al., 1996).

Thus, the objectives of this review were to characterize herbicide selectivity by differential metabolism; to present the main metabolic pathways associated with selectivity; to define the phytotoxicity concept and the intrinsic potential of additional energy waste that might lead to yield losses; and to propose experimental and practical alternatives to improve herbicide selectivity in crops.

\section{Herbicide metabolism}

The main mechanism of herbicide selectivity is the differential metabolism between weeds and crop species, by which susceptible weeds are less able to metabolize selective herbicides (Devine et al., 1993; Cole, 1994). In plants, differential metabolism of herbicides is characterized by the conversion of lethal molecules to less toxic compounds, to be stored where they would not affect plant cell survival. One plant species containing such mechanisms can alter or degrade the herbicide molecule by biochemical reactions producing non-toxic products (Oliveira Júnior, 2001).

Herbicide metabolism can be caused by a natural metabolic process of plant detoxification, usually classified into four main phases (Yuan et al., 2007): Phase I, also known as conversion; Phase II or conjugation; Phase III with secondary conversion and transport into vacuole; and Phase IV with deposition of final metabolite (Devine et al., 1993; Cole, 1994; Eerd et al., 2003; Yuan et al., 2007). Edwards et al. (2005) considered the metabolic processes of herbicide detoxification in plants as the 'Xenome', or the biosystem responsible for detection, transport and biotransformation of xenobiotics in the cell.

During Phase I of herbicide metabolism, the active ingredient molecules suffer chemical modifications, such as oxidation; reduction; hydrolysis; oxygenation; or hydroxylation, when functional groups $\left(\mathrm{OH}, \mathrm{NH}_{2}, \mathrm{COOH}\right)$ are introduced or revealed, making the molecule more hydrophilic, and therefore less phytotoxic (Devine et al., 1993; Eerd et al., 2003; Edward et al., 2005; Yuan et al., 2007). The most important enzymes involved in are Cytochrome P450 monooxygenases (P450s) (Eerd et al., 2003; Yuan et al., 2007), which are membrane-bound haem proteins that catalyze oxy-reduction reactions of endogenous and xenobiotic substrates (Bolwell et al., 1994; Persans et al., 2001; Hatzios \& Burgos, 2004; Edwards et al., 2005). In fact, Cytochromes P450 are a large family of enzymes responsible for the addition of a single atom of oxygen to hydrophobic substrates (Bolwell et al., 1994; Preston, 2004). The group of herbicides more sensitive to the P450 action includes the sulfonylurea and some imidazolinones.

During Phase II, the herbicide molecule or the metabolite derived from Phase I is conjugated with sugars, amino acids or with the tripeptide Glutathione, increasing the solubility in water, while reducing phytotoxicity. Many herbicides that contain specific radicals in their molecule can be directly conjugated, starting their metabolism directly on Phase II (Devine et al., 1993). In general, metabolites originated in Phase II have low or no herbicidal activity, and they can be stored in cell organelles (Eerd et al., 2003).

Among the possible mechanisms for conjugation in Phase II, the most important, found in the majority of plant species is the conjugation with Glutathione (tripeptide $\gamma$-Glu-Cys-Gly or GSH), with Homo-Glutathione (tripeptide $\gamma$-Glu-Cys- $\beta$-Ala or hGSH) (Figure 1), or with Glucose. The presence of Glutathione or Homo-Glutathione depends on the plant species, with hGSH more common in many leguminous species, such as the soybean (Glycine max) and common beans (Phaseolus vulgaris), for example (Price, 1957; Carnegie, 1963; McGonigle et al., 1998).

The Glutathione-S-transferases (GST) are the enzymes responsible for GSH conjugation with herbicide metabolites (Devine et al., 1993; Cole, 1994; McGonigle et al., 1998; Eerd et al., 2003). GSTs catalyze the nucleophillic substitution of the Sulfur atom from GSH or hGSH (Figure 1) by the electrophilic cen- 
ter of the herbicide (Marrs, 1996; McGonigle et al., 1998; Eerd et al., 2003). According to McGonigle et al. (2000), GSTs are present at every stage of plant development from early embryogenesis to senescence and in every tissue type examined.

The herbicides conjugated by the GSTs include those from the group of Sulfonylureas, Imidazolinones, Aryloxy-phenoxy-propionates, Triazins and Chloroacetanilide. The enzymes responsible for conjugation with Glucose are the Glycosyl-Transferases (GTs), that similarly to GSTs, can conjugate herbicides directly, by glycolsylation of specific functional groups of lipophillic molecules, such as $-\mathrm{OH},-\mathrm{COOH},-\mathrm{NH}_{2}$ and -SH (Yuan et al., 2007).

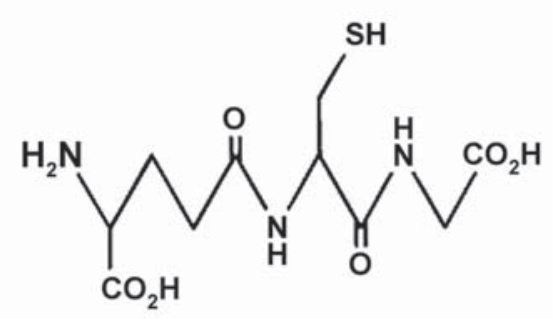

Glutathione

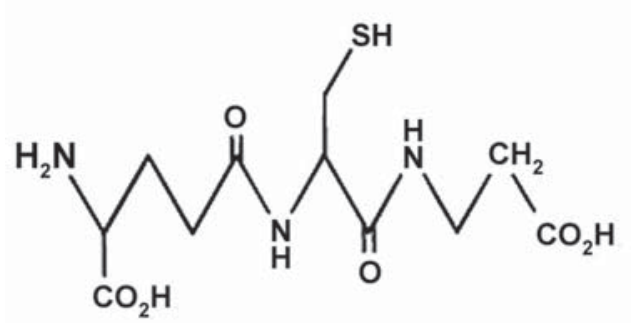

Homo-Glutathione

Figure 1 - Molecular structure of Glutathione (GSH) and HomoGlutathione (hGSH). Adapted from McGonigle et al. (1998).
During Phase III, the metabolites derived from Phase II are actively transported to the vacuole by mostly ABC (ATP binding cassete) transporters (Yuan et al., 2007). Secondary conjugations might also occur during Phase III, giving origin to non-phytotoxic compounds (Hatzios, 1991). Later, in Phase IV, the metabolites of the detoxification process, compartmentalized in vacuoles, may be associated with components of the cell wall (pectin, lignin, polyssacharides, and protein fractions) forming insoluble residues (Pillmoor et al., 1984; Langebartels \& Harms, 1985; Cole, 1994; Edwards et al., 2005). The reactions, solubility, phytotoxicity and mobility of metabolites in plants during the herbicide detoxification process over the four Phases are listed in Table 1.

The importance of understanding the main stages of differential metabolism-based selectivity derives from the elucidation that plants, to a small or a large extent, use cell energy to process and detoxify herbicides. However, enzymes such as cytochrome P450s and GSTs naturally occur in plants, in multiple isoforms, eventually catalyzing important reactions of secondary metabolism (Timmerman, 1989; Donaldson \& Luster, 1991; Bolwell et al., 1994; Persans et al., 2001; Hatzios \& Burgos, 2004). For example, the status of plant cytochrome P450 research was reviewed by Bolwell et al. (1994), who discussed the commitment of P450s with the biosynthesis of lipids, phenylpropanoids, flavonoids, coumarins, terpenoids, cyanogenic glucosides and alkaloids.

In addition, glutathione (GSH) can be found at relatively high concentrations in most plant tissues (Rennenberg, 1982; McGonigle et al., 1998), involved in processes associated with products from secondary metabolism of plants (Eerd et al., 2003), with regulation and transport of exogenous and endogenous compounds (Hatzios, 1991; McGonigle et al., 2000), and with protection against oxidative stress caused by pests

Table 1 - Summary of the herbicide metabolism phases in plants. Adapted from Eerd et al. (2003) and Shimabukuro (1985), with small changes.

\begin{tabular}{|c|c|c|c|c|c|}
\hline Characteristics & $\begin{array}{c}\text { Initial } \\
\text { Properties }\end{array}$ & Phase I & Phase II & Phase III & Phase IV \\
\hline Reactions & $\begin{array}{l}\text { Herbicidal } \\
\text { Action }\end{array}$ & $\begin{array}{c}\text { Oxidation, Reduction, } \\
\text { Hydrolysis, Oxygenation, } \\
\text { Hydroxylation }\end{array}$ & $\begin{array}{l}\text { Conjugation with } \\
\text { amino acids, } \\
\text { glucose or sugar }\end{array}$ & $\begin{array}{l}\text { Secondary conjugation; } \\
\text { compartmentalization in } \\
\text { vacuoles }\end{array}$ & $\begin{array}{l}\text { Association to } \\
\text { cell wall } \\
\text { components }\end{array}$ \\
\hline Solubility & Lipophilic & Intermediary & Hydrophilic & Hydrophilic & Insoluble \\
\hline Phytotoxicity & $\begin{array}{l}\text { High - } \\
\text { herbicidal action }\end{array}$ & Modified or less toxic & $\begin{array}{l}\text { Reduced or non- } \\
\text { toxic }\end{array}$ & Non-phytotoxic & Non-phytotoxic \\
\hline Mobility in Plants & $\begin{array}{l}\text { Variable as } \\
\text { function of } \\
\text { herbicide }\end{array}$ & Modified or reduced & $\begin{array}{l}\text { Limited or } \\
\text { immobile }\end{array}$ & Immobile & Immobile \\
\hline
\end{tabular}


and pathogens, metal exposure, or air pollutants (Dudler et al., 1991; Sharma \& Davis, 1994; Cole, 1994; Kusaba et al., 1996; Marrs, 1996; Eerd et al., 2003).

Therefore, despite the energy disposal, metabolic herbicide tolerance in plants may be considered a natural physiological response to stress causes, which also might be used against non-herbicidal endogenous or exogenous compounds, including natural molecules, and if kept within limits might not compromise crop yield.

\section{Phytotoxicity and yield losses}

When a plant is exposed to a stressful condition, in which the tolerance threshold is reached, latent physiological or metabolic distresses are revealed as irreversible injuries or chronic symptoms (Larcher, 2000). In the case of selectivity, the amount of visible injuries presented by a plant in consequence of herbicide application is named phytotoxicity. Therefore, phytotoxicity can be interpreted as the overcome of the maximum protection capacity offered by the group of selectivity factors, whereas considering metabolism as the main factor, as the overcome of the species intrinsic ability to detoxify an unfamiliar molecule to the natural metabolism of the plant.

In this way, in tolerant plants, part of the herbicide is taken up, quickly metabolized and inactivated before exerting its phytotoxic effects (Oliveira Júnior, 2001). However, part of the herbicide reaches the target site of action, leading the plant to express symptoms. Basically, phytotoxicity symptoms can be divided into structural damage (chlorosis; necrosis; albinism; wilt; epinasty; and leaf shriveling or rolling) or physiological damage (cycle reduction; growth rate reduction). There are a few specific reports estimating reconstruction costs of structural damages caused by herbicides; although there are some general energetic cost estimates for compound and structure synthesis (Merino et al., 1984; Gulmon \& Mooney, 1986; Williams et al., 1987; Diamantoglou et al., 1989; Kull et al., 1992; Larcher, 2000).

In phytotoxic cases, energy disposal of a plant treated with an herbicide with partial selectivity occurs through two processes. The first process is due to the rapid metabolization of part of the herbicide molecules, and the second is related with the recovering from damages caused by molecules that reached the herbicide site of action. Even considering that the energy used in metabolic processes of detoxification is naturally available and does not cause losses in crop yield, the energy for recovering damaged structures (phytotoxicity) may not be considered as a natural physiological response, in a way that plant recovery can result in a larger or smaller yield losses.
Some plants during certain stages of development present a considerable tolerance to defoliation (ex. soybean) or to the loss of tillers (ex. sugarcane), with significant compensatory effects. In these cases, the presence of only structural damages looses importance for the physiological damages, mainly when related to effects on growth (Figure 2). Some agrochemicals can affect Cytochrome P450 systems, modifying product metabolization (Eerd et al., 2003). In this case, enzyme activity is stimulated (safeners) or repressed (decrease in selectivity), which could affect plant growth and development.

The application of an herbicide might result in a case of temporary or permanent stress (Larcher, 2000), depending on the characteristics of the product (mode of application and rate), of the crop (cultivar or hybrid; stage of development; nutrition; water balance); and of the environment (Oliveira Júnior, 2001; López-Ovejero et al., 2003). Temporary stress allows rapid plant recovery from damage, with later recuperation of the initial growth rate, with or without yield losses, but with relevant changes in the crop cycle. On the other hand, permanent stress imposes a distinct plant growth rate, lower than the initial one, in a way that the probability of yield losses is greater (Figure 2). The condition for reduced growth rate, after herbicide application over a large area, might not be noticed by the grower, mainly if the damages were characterized since pre-emergence application, without comparative check plots and without weed interference.

There are several articles reporting yield losses or changes in growth caused by serious phytotoxicity. Arruda et al. (1999), for example, observed that the pre-emergence application of sulfentrazone reduced growth of soybean cultivars with low tolerance to the

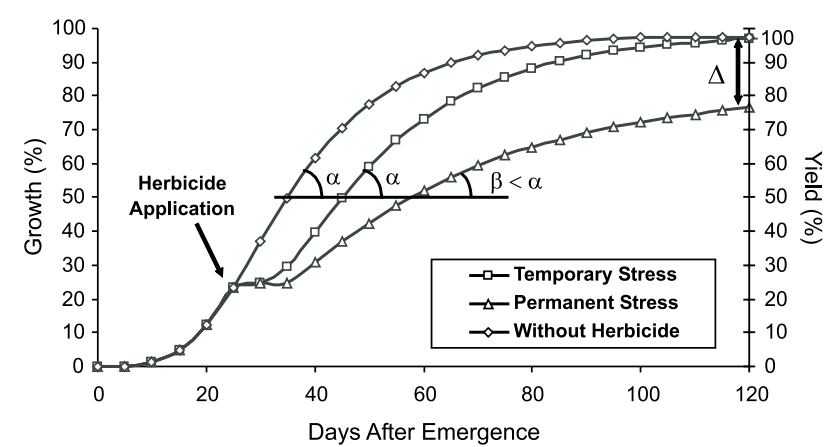

Figure 2 - Mathematical models of herbicide phytotoxicity effects on crop growth and yield. Temporary stress: plant recovers damage without definitive changes on growth rate $(\alpha)$. Permanent stress: after partial recovery, the growth rate is permanently damaged $(\beta<\alpha)$. $\Delta$ represents the estimative of yield final reduction. Adapted from Larcher (2000). 
product, leading to reduced leaf area, total dry matter, and mainly dry root matter. Similar results were described by Young et al. (2003), caused by the application of imazethapyr and acifluorfen. For maize, the combined application of organo-phosphorate insecticides and sulfonylurea herbicides can reduce maize herbicide tolerance, resulting in smaller yields (Porpiglia et al., 1990; Morton et al., 1991). Application of trifloxysulfuron-sodium in early stages of cotton development reduced the accumulation of dry matter (Freitas et al., 2005a), whereas application under recommended rate and stage of development presented signs of phytotoxicity that affected crop cycle, and just temporarily the plant growth rate, which did not reduce cotton yield (Freitas et al., 2005b; Freitas et al., 2006).

\section{Tools to ensure crop yield}

Selectivity by differential metabolism is the main mechanism that allows the application of herbicides in pre- or post-emergence, with minimal damages to the crop. Selectivity cannot be determined only by evaluating visual symptoms of intoxication, because there are examples of herbicides that can reduce crop yield without producing visually detectable effects, whereas there are examples of those which induce serious injuries, while maintaining full yield potential of affected crops. However, in some conditions, crop losses are observed after application of herbicides considered selective, even though within recommendation limits. Thus, there are two main agronomic tools that could be applied to minimize herbicide phytotoxicity, and consequently, decrease crop yield losses: (i) experimental approach (more trustable results), and (ii) practical approach (Table 2).

In terms of agricultural experimentation, some concepts must be reviewed in scientific literature that evaluates herbicide selectivity: a. Controls (checks), trial conduction and experimental area homogeneity: the checks and all the other plots of a selectivity experiment must be permanently weeded, to avoid interference from weeds (Velini, 1995; Souza et al., 2002). The trials must be established under rigorous environmental control, either by increasing the number of replicates (which sometimes is not sufficient), or by adopting double, paired or lateral checks (Fagliari et al., 2001; Constantin et al., 2003);

b. Variables and data evaluation: Selectivity trials must include, besides visual evaluation of the damage, evaluations of crop yield, since there are herbicides that cause significant injuries but the growth recovery allows the re-establishment of potential yield (temporary stress), but there are herbicides that do not induce visual symptoms (hidden phytotoxicity), but affect the growth rate (permanent stress) (Velini et al., 1992; Velini et al., 1995a). In the same way, harvesting of experimental plots must be carried out carefully, with precision, trying to avoid estimations based on small samples. Increasing precision and reducing variability may improve the chance to detect even small decreases in crop yields;

c. Use of less rigorous statistical tests: Tukey's test is rigorous, and, therefore is appropriated to identify large differences. In selectivity experiments, the objective is to demonstrate the absence of difference, thus small differences are important to be detected. Less sensitive tests, such as the 't-test' (Azania et al., 2005), the 'Duncan'test; or large probabilities (Velini et al., 1995b) would better fit the experimental goals.

In terms of efficient practical strategies to ensure herbicide selectivity, the following points must be considered:

Table 2 - Experimental and practical measures to increase herbicide selectivity to crops.

\begin{tabular}{ll}
\hline Measures & \multicolumn{1}{c}{ Examples } \\
\hline & 1. Accuracy on trial installation and conduction \\
2. Maintain all the checks and other plots permanently weeded \\
3. Highly control the intrinsic variability of experimental areas \\
4. Always evaluate crop yield parameters \\
$\begin{array}{ll}\text { 5. Accuracy on the moment of data evaluation (plot harvest) } \\
\text { 6. Application of less rigorous statistical tests or probabilities }\end{array}$ \\
$\begin{array}{ll}\text { 1. Chose consciously the herbicide, rate and application timing } \\
\text { 2. Adequate crop cultivar or hybrid to herbicide and weather condition }\end{array}$ \\
$\begin{array}{ll}\text { 3. Exercise care over all the possible chemical interaction } \\
\text { 4. Use of antidotes or safeners } \\
\text { 5. Whenever possible, adopt enzymatic-insensitivity selective herbicides }\end{array}$ \\
\hline 6. Adopt genetically modified crops tolerant to herbicides
\end{tabular}


a. Follow recommendations of Good Agricultural Practices in terms of rate, product and mixtures, timing of application; cultivar or hybrid; and environmental conditions;

b. Exercise care in relation to product (chemicals) interaction, mainly herbicides and organo-phosphorate insecticides applied together or at short intervals between applications (Porpiglia et al., 1990; Morton et al., 1991);

c. Use antidotes or safeners, always when recommended (Devine et al., 1993; Oliveira Júnior, 2001; Hatzios \& Burgos, 2004; Foloni et al., 2005);

d. Whenever possible, rank herbicide applications according to selectivity, starting with products with enzymatic insensitivity, such as ACCase inhibitor (Turner \& Pernich, 2002) in soybean, cotton and dry beans;

e. Adopt genetically modified crops tolerant to herbicides (Pline-Srnic, 2005; Heck et al., 2005).

\section{CONCLUDING REMARKS}

Due to constant raise in social pressure for increase in food, fiber and energy production, sometimes the concept of selectivity has not been carefully applied, while the rational should be just the opposite. Herbicide selectivity is an agricultural technology that has been widely exploited in chemical weed control strategies, but it may also be seen as a major aspect that can result in yield losses. Herbicide metabolism is related to energy disposal, and hence, phytotoxicity symptoms characterize a second energy expenditure that should not be accepted as a natural physiological response, that might result in crop yield losses.

Weeds, when interfering with the crop, reduce quality and yield. The herbicides, however, are tools used to avoid these losses, and thus, it is not reasonable that when herbicides are applied, they also might represent risks to yield losses (phytotoxicity). To avoid or reduce crop losses and injuries, it is necessary that herbicide recommendations are based on selectivity assays conducted under rigorous experimental procedures, as well as, it is important to increase growers' awareness about the best use for each product.

\section{REFERENCES}

ARRUDA, J.S.; LOPES, N.F.; BACARIN, M.A. Crescimento de plantas de soja em função de doses de sulfentrazone. Planta Daninha, v.17, p.375-386, 1999.

AZANIA, C.A.M.; ROLIM, J.C.; CASAGRANDE, A.A.; LAVORENTI, N.A.; AZANIA, A.A.P.M. Herbicide selectivity. I. Use of additional check methods in sugarcane experiments. Planta Daninha, v.23, p.661-667, 2005.
BOLWELL, G.P.; BOZAK, K.; ZIMMRELIN, A. Plant cytochrome P450. Phytochemistry, v.37, p.1491-1506, 1994.

CARNEGIE, P.R. Structure and properties of homologue of glutathione. Biochemical Journal, v.89, p.471, 1963.

COLE, D.J. Detoxification and activation of agrochemicals in plants. Pesticide Science, v.42, p.209-222, 1994.

CONSTANTIN, J.; OLIVEIRA JÚNIOR, R.S.; MARCHIORI JÚNIOR., O.; CARREIRA, S.A.M.; FAGLIARI, J.R.; PAGLIARI, P.H.; PIVETTA, J.P. Seletividade de isoxaflutole aplicado isoladamente e conjuntamente com diuron+hexazinone em cana-de-açúcar em pré e pós-emergência. STAB, v.22, p.34-38, 2003.

DEVINE, M.; DUKE, S.O.; FEDTKE, C. Physiology of herbicide action. Englewood Cliffs: Prentice Hall, 1993. 441p.

DIAMANTOGLOU, S.; RHIZOPOULOU, S.; KULL, U. Energy content, storage substances, and construction and maintenance costs of Mediterranean deciduous leaves. Oecologia, v.81, p.528-533, 1989.

DONALDSON, R.P.; LUSTER, D.G. Multiple forms of plant cytochromes P-450. Plant Physiology, v.96, p.669-674, 1991.

DUDLER, R.; HERTIG, C.; REBMANN, G.; BULL, J.; MAUCH F. A pathogen-induced wheat gene encodes a protein homologous to glutathione-S-transferases. Molecular Plant-Microbe Interactions, v.4, p.14-18, 1991.

EDWARDS, R.; BRAZIER-HICKS, M.; DIXON, DP., CUMMINS, I. Chemical manipulation of antioxidant defenses in plants. Advances in Botanical Research, v.42, p.1-32, 2005.

EERD, L.L. van; HOAGLAND, R.E.; ZABLOTOWICZ, R.M.; HALL, J.C. Pesticide metabolism in plants and microorganisms. Weed Science, v.51, p.472-495, 2003.

FAGLIARI, J.R.; OLIVEIRA JÚNIOR, R.S.; CONSTANTIN, J. Métodos de avaliação da seletividade de herbicidas para a cultura da cana-de-açúcar (Saccharum spp.). Acta Scientiarum, v.23, p.1229-1234, 2001.

FOLONI, L.L.; BIZARI, D.R.; SOUZA, E.L.C.; CASSINELI, M.; Seletividade de clomazone aplicado em pré-emergência, em sementes tratadas com dietholate (teor de argila entre 10 a 30\%). In: CONGRESSO BRASILEIRO DE ALGODÃO, 5., Salvador, 2005. Anais. Salvador, 2005. CDROM.

FREITAS, R.S.; TOMAZ, M.A.; FERREIRA, L.R.; BERGER, P.G.; PEREIRA, C.J.; CECON, P.R.V. Growth of cotton treated with trifloxysulfuron-sodium. Planta Daninha, v.24, p.123-129, 2006.

FREITAS, R.S.; BERGER, P.G.; TOMAZ, M.A.; FERREIRA, L.R.; PEREIRA, C.J.; CECON, P.R. Efeitos do herbicida trifloxysulfuron-sodium no crescimento do algodoeiro. In: CONGRESSO BRASILEIRO DE ALGODÃO, 5., Salvador, 2005. Anais. Salvador, 2005b. CD-ROM.

FREITAS, R.S.; CARNEIRO, P.A.M.; CECON, P.R.; FERREIRA, L.R.; BERGER, P.G.; SEDIYAMA, T. Tolerância do algodoeiro em três estádios de desenvolvimento submetido ao herbicida trifloxysulfuron-sodium. In: CONGRESSO BRASILEIRO DE ALGODÃO, 5., Salvador, 2005. Anais. Salvador, 2005a. CDROM.

GULMON, S.L.; MOONEY, H.A. Costs of defense on plant productivity. In: GIVNICH, T.J. (Ed.) On the economy of plant form and function. Cambridge: Cambridge University Press, 1986. p.681-698.

HATTON, P.J.; DIXON, D.; COLE, D.J.; EDWARDS, R. Glutathione transferase activities and herbicide selectivity in maize and associated weed species. Pesticide Science, v.46, p.267-275, 1996.

HATZIOS, K.K. Biotransformations of herbicides in higher plants. In: GROVER, R.; CESSNA, A.J. (Ed.) Environmental chemistry of herbicides. Boca Raton: CRC Press, 1991. p.141185 .

HATZIOS, K.K.; BURGOS, N. Metabolism-based herbicide resistance: regulation by safeners. Weed Science, v.52, p.454467, 2004. 
HECK, G.R.; ARMSTRONG, C.L.; ASTWOOD, J.D.; BEHR, C.F.; BOOKOUT, J.T.; BROWN, S.M.; CAVATO, T.A.; DEBOER, D.L.; DENG, M.Y.; GEORGE, C.; HILLYARD, J.R.; HIRONAKA, C.M.; HOWE, A.R.; JAKSE, E.H.; LEDESMA, B.E.; LEE, T.C.; LIRETTE, R.P.; MANGANO, M.L.; MUTZ, J.N.; QI, Y.; RODRIGUEZ, R.E.; SIDHU, S.R.; SILVANOVICH, A.; STOECKER, M.A.; YINGLING, R.A.; YOU, J. Development and characterization of a CP4 EPSPS-based, glyphosate-tolerant corn event. Crop Science, v.45, p.329-339, 2005.

KULL, U.; HERBIG, A.; FREI, O. Construction and economy of plant stems as revealed by use of the Bic-method. Annals of Botany, v.69, p.327-334, 1992.

KUSABA, M.; TAKAHASHI, Y.; NAGATA, T. A multiple-stimuliresponsive as-1-related element of parA gene confers responsiveness to cadmium but not to copper. Plant Physiology, v.111, p.1161-1167, 1996.

LANGEBARTELS, C.; HARMS, H. Analysis for nonextractable (bound) residues of pentachlorophenol in plant cells using a cell wall fractionation procedure. Ecotoxicology and Environmental Safety, v.10, p.268-279, 1985.

LARCHER, W. Ecofisiologia vegetal. São Carlos: RiMa, 2000. $531 \mathrm{p}$.

LÓPEZ-OVEJERO, R.F.; CHRISTOFFOLETI, P.J.; NICOLAI, M; BARELA, J.F. Manejo de plantas daninhas na cultura do milho. In: FANCELli, A.L; DOURADO-NeTO, D. (Ed.) Milho: estratégias de manejo para alta produtividade. Piracicaba: USP/ ESALQ, 2003. p 47-79.

MARRS, K.A. The functions and regulation of glutathione Stransferases in plants. Annual Review of Plant Physiology and Plant Molecular Biology, v.47, p.127-158, 1996.

McGONIGLE, B.; LAU, S.M.C.; JENNINGS, L.D.; O'KEEFE, D.P. Homoglutathione selectivity by soybean glutathione stransferases. Pesticide Biochemistry and Physiology, v.62, p.15-25, 1998.

McGONIGLE, B.; KEELER, S.J.; LAU, S.M.C.; KOEPPE, M.K.; O'KEEFE, D.P. A genomics approach to the comprehensive analysis of the glutathione $s$-transferase gene family in soybean and maize. Plant Physiology, v.124, p.1105-1120, 2000.

MERINO, J.; FIELD, C.; MOONEY, H.A. Construction and maintenance costs of mediterranean-climate evergreen and deciduous leaves. Acta Oecologica, v.5, p.211-229, 1984.

MORTON, C.A.; HARVEY, R.G.; KELLS, J.J.; LUESCHEN, W.E.; FRITZ, V.A. Effect of DPX-V9360 and terbufos on field and sweet corn (Zea mays) under three enviroments. Weed Technology, v.5, p.130-136, 1991.

NEGRISOLI, E.; VELINI, E.D.; TOFOLI, G.R.; CAVENAGHI, A.L.; MARTINS, D.; MORELLI, J.L.; COSTA, A.G.F. Selectivity of pre-emergence herbicides to sugarcane treated with nematicides. Planta Daninha, v.22, p.567-575, 2004.

OLIVEIRA JÚNIOR, R.S. Seletividade de herbicidas para culturas e plantas daninhas. In: OLIVEIRA JÚNIOR, R.S.; CONSTANTIN, J. Plantas daninhas e seu manejo. Guaíba: Agropecuária, 2001. p. 291-313.

PERSANS, M.W.; WANG, J.; SCHULER, M.A. Characterization of maize cytochrome P450 monooxygenases induced in response to safeners and bacterial pathogens. Plant Physiology, v.125, p.1126-1138, 2001.

PILLMOOR, J.B.; GAUNT, J.K.; ROBERTS, T.R. Examination of bound (non-extractable) residues of MCPA and flamprop in wheat straw. Pesticide Science, v.15, p.375-381, 1984.

PLINE-SRNIC, W. Technical performance of some commercial glyphosate-resistant crops. Pest Management Science, v.61, p.225-234, 2005.
PORPIGLIA, P.J.; RAWLS, E.K.; GILLESPIE, G.R.; PEEK, J.W. A method to evaluate the differential response of corn (Zea mays) to sulfonylureas. WSSA Abstracts, v.30, p.86, 1990.

PRESTON, C. Herbicide resistance in weeds endowed by enhanced detoxification: complications for management. Weed Science, v.52, p.448-453, 2004.

PRICE, C.A. A new thiol in legumes. Nature, v.180, p.148, 1957.

RENNENBERG, H. Glutathione metabolism and possible biological roles in higher plants. Phytochemistry, v.21, p.2771-2781, 1982.

SHARMA, Y.K.; DAVIS, K.R. Ozone-induced expression of stressrelated genes in Arabidopsis thaliana. Plant Physiology, v.105, p.1089-1096, 1994.

SHIMABUKURO, R.H. Detoxification of herbicides. In: DUKE, S.O. (Ed.) Weed physiology. Boca Raton: CRC Press, 1985. v.2, p.215-240.

SOUZA, R.T.; CONSTANTIN, J.; VELINI, E.D.; MONTORIO, G.A.; MACIEL, C.D.G. Selectivity of latifolicide herbicide combinations with lactofen for the soybean crop. Scientia Agricola, v.59, p.99-106, 2002.

TIMMERMAN, K.P. Molecular characterization of corn glutathione-S-transferase isoenzymes involved in herbicide detoxification. Physiologia Plantarum, v.77, p.465-471, 1989.

TURNER, J.A.; PERNICH, D.J. Origin of enantiomeric selectivity in the aryloxyphenoxypropionic acid class of herbicidal acetyl coenzyme A carboxylase (ACCase) inhibitors. Journal of Agriculture and Food Chemistry, v.50, p.4554-4566, 2002.

VELINI, E.D. Estudo e desenvolvimento de métodos experimentais e amostrais adaptados à matologia. Jaboticabal: UNESP/FCA, 1995. 250p. (Doutorado).

VELINI, E.D.; FREDERICO, L.A.; ORSI JÚNIOR, F.; VALÉRIO, W.G.; MORAIS JÚNIOR, E.C. Avaliação da seletividade do clomazone, aplicado em pré ou pós-emergência, a dez variedades de cana-de-açúcar (cana-planta). In: CONGRESSO BRASILEIRO DA CIÊNCIA DAS PLANTAS DANINHAS, 20., Florianópolis, 1995. Anais. Florianópolis: SBCPD, 1995b. p.221-222.

VELINI, E.D.; FREDERICO, L.A.; MORELLI, J.L.; MARUBAIASHU, O.M. Avaliação dos efeitos de doses do herbicida clomazone, aplicado em pós-emergência inicial, sobre o crescimento e produtividade de soqueira de cana-de-açúcar (Saccharum officinarum cv. SP 71-1406). STAB, v.10, p.1316, 1992.

VELINI, E.D.; OSIPE, R.; GAZZIERO, D.L.P. Procedimentos para instalação, avaliação e análise de experimentos com herbicidas. Londrina: SBCPD, 1995a. 42p.

WILLIAMS, K., PERCIVAL, F.; MERINO, J.; MOONEY, H. A. Estimation of tissue construction cost from heat of combustion and organic nitrogen content. Plant Cell Environment, v.10, p.725-734, 1987.

YOUNG, B.G.; YOUNG, J.M.; MATTHEWS; J.L.; OWEN, M.D.K.; ZELAYA; I.A.; HARTZLER, R.G.; WAX, L.M.; ROREM, K.W.; BOLLERO, G.A. Soybean development and yield as affected by three postemergence herbicides. Agronomy Journal, v.95, p.1152-1156, 2003.

YUAN, J.S.; TRANEL, P.J.; STEWART JR., C.N. Non-target-site herbicide resistance: a family business. Trends in Plant Science, v.12, p.6-13, 2007.

Received August 27, 2007

Accepted July 15, 2008 